\title{
Disaster Mitigation in Early Childhood Education
}

\author{
Ina Winangsih ${ }^{1, *}$ Euis Kurniati ${ }^{1}$
}

\author{
${ }^{1}$ Department of Early Childhood Education, School of Postgraduates, Universitas Pendidikan Indonesia, Bandung, \\ Indonesia \\ *Corresponding author. Email: ina@upi.edu
}

\section{ABSTRACT}

Natural disaster happens quite frequently in Indonesia. The Government has attempted to tackle natural disaster by developing disaster mitigation mainstreaming plan in almost every aspect of the country's development fields, including in education. However, early childhood education remains overlooked in the discussion pertaining the natural disaster. Using a literature review approach, this paper aims to elaborate why early childhood education needs to be included in the nation's disaster mitigation mainstreaming program. The finding of this paper is expected to illuminate how early childhood education program should be designed in order to be responsive with the natural disaster.

Keywords: Disaster mitigation, early childhood education

\section{INTRODUCTION}

Indonesia's geographical location is traversed by the ring of fire, where series of active volcanoes are spread along the path (Amri, Bird, Ronan, Haynes, \& Towers, 2017; Desfandi, 2014; Honesti \& Djali, 2012; Sair, 2019; Subagia, 2017). It puts Indonesia into one of the most disaster-prone countries in the world (Djalante, Garschagen, Thomalla, \& Shaw, 2017). Every year, Indonesia is affected by numerous natural disasters that claim both material losses (James, 2008) and life costs (Subagia, 2017; Suryani, 2017). One of the factors that contributes to the amount of losses is the high level of vulnerability in natural disaster among Indonesian society (Siagian, Purhadi, Suhartono, \& Ritonga, 2014). This phenomena can be further shown in situations such as the lack of awareness of natural disasters in the area in which the residents live, the low level of literacy about disasters in the community (Kusumawardhani, 2019), and the lack of sustainable development activities. Therefore, material losses and life costs would still be in high level every time natural disaster occurs.

One of the notes that should be focused on from the impacts of natural disaster is the high number of victims at the age of children (Belter \& Shannon, 1993) because in the context of disasters, children is considered as vulnerable populations (World Health Organization, 2002; Amri et al., 2017; Inter-Agency Standing Committee (IASC), 2013). Besides children, natural disasters also cause high rates of damages in school facilities (Kousky, 2016). Due to the fact that natural disasters can occur in any time, school should be one of the places where people can feel safe (Stough, Kang, \& Lee, 2018). Thus, according to said situations, attention to children and school in the context of disasters needs to be increased (Badan Nasional Penanggulangan Bencana, 2012). As explained by Mutasa \& Munsaka (2019) and Stough et al. (2018), disaster mitigation is important to be implemented in children and education institutions.

Disaster mitigation is explained as an effort to reduce disaster risks. It is written in Indonesian Government Regulation No 21 in the year 2008 (Pemerintah Republik Indonesia, 2008). that "Mitigation is a series of effort to reduce disaster risks, both from physical development or awareness raising and capacity building to face the threat of disasters". Disaster perspective has been changed into not only about emergency response, but also about disaster mitigation cycle. The mitigation efforts can be done by implementing disaster preparedness education, reducing disaster vulnerability, raising capacity, drawing up an emergency plan, etc. (UNISDR, 2009).

There are various other researches that show the importance of disaster mitigation in school Stough et al. (2018) and the success of disaster education in the students' preparedness Adiyoso \& Kanegae (2012). Even though Tuswadi (2014) still found that ineffective teaching of disasters could not be grasped fully by children in his research, but research about disaster risk reduction in preschool has been done by Proulx (2019), showing that disaster risks reduction intervention provides an increase in the quality of school environment and children knowledge about natural disaster. Thus, it can be concluded that disaster mitigation in school still needs to have a lot of trials and to be tested.

This journal attempts to see why Early Childhood Education as a whole should play a role in disaster mitigation in Indonesia. Filling the gaps of other researches that still focus on formal early childhood education such as kindergarten, the results of this literature study are expected to provide an overview of the urgency of implementing a disaster mitigation in early childhood education in Indonesia as a whole. Thus, it could give a consideration to raise the effort in disaster awareness in 
early childhood education for policy makers, parents, and teachers

\section{LITERATURE REVIEW}

This journal uses post-developmentalism perspective in analyzing how early childhood education can play a role in disaster mitigation in Indonesia. Post-developmentalism theory believes that children have the same capability as adults (Burman, 2008). Therefore, in the context of disaster mitigation, early childhood is not only seen as vulnerable population, but also has resilience, (Ronan, Haynes, Amri, \& Frontiers, 2016), qualities and potentials. In his research, Freeman (2015) found that children that have gone through disaster period show their resiliency by giving out advise that focuses on their role in disastrous situations. It shows that the effort to reduce disaster risks in early childhood is possible.

Early childhood may get effective education from both parents (Guo \& Kilderry, 2018) and school (Izadkhah \& Gibbs, 2015). The education that the children received in their early years would give a prolonged effect up to the point of adulthood (Shadbegian, Guignet, Klemick, \& Bui, 2019). Given to the role of the school as a place for children to learn and shape themselves into a better behavior (Elangovan \& Kasi, 2014; Septiadi, 2012), disaster mitigation should also be implemented in schools (Back, Cameron, \& Tanner, 2009). In this case, early childhood education institutions, the place where children receive their education outside home environment, have important role in disaster mitigation. If disaster mitigation can be implemented in family and school environment, it would be easier for children to learn crucial issues in their community.

In Indonesia, early childhood education institutions are divided into two types, which are formal and nonformal. It is written by Kemendikbud (2014) in Indonesian Education and Culture Ministry Regulation No 14 Year 2014 (Permendikbud No 14 Tahun 2014) regarding Early Childhood Education National Standard, that Early Childhood Education institutions can be given in the forms of Kindergarten (Taman Kanak-Kanak), Kindergarten Under the Regulation of Ministry of Religion (Raudhatul Athfal), Childcare (Taman Penitipan Anak), and Other Similar Early Childhood Education Institution (Satuan $P A U D$ Sejenis), where in each and every institution, there would be teacher and parent roles implemented. Teachers and parents would have a great effect in disaster mitigation effort in children (Kousky, 2016; Kusumawardhani, 2019). In the post-developmentalism perspective, the early childhoods, even though are not eligible for a more formal education institution such as kindergarten, have already show potentials to receive disaster education. Therefore, it is suggested for teachers and parents to take initiative and implement disaster education in early childhood, even though the curriculum, programs (Proulx \& Aboud, 2019), or even regulations (Adiyoso \& Kanegae, 2012) regarding disaster mitigations in early childhood in Indonesia have room to be improved.

The disaster mitigation that would be implemented in children should certainly actively involve children. The training for disaster preparedness would be more effective if done with parents (Ronan, Johnston, Paton, \& Becker, 2008) and teachers (Elangovan \& Kasi, 2014). Disaster may have happened when children are both in home or in school. Therefore, the involvement of disaster mitigation should be done comprehensively, including the roles of all school board, parents, and the community.

\section{METHOD}

This journal uses meta-analysis method, by discussing eight researches regarding the efforts of disaster mitigation implementation in children. The researcher are done both in Indonesia (Adiyoso \& Kanegae, 2012; Amri et al., 2017; Proulx \& Aboud, 2019), and outside of Indonesia (Elangovan \& Kasi, 2014; Izadkhah \& Gibbs, 2015; Pfefferbaum, Pfefferbaum, \& Van Horn, 2018; K. R. Ronan et al., 2008; Tatebe \& Mutch, 2015). From said researches, this paper would explain why disaster mitigation should be implemented in early childhood education in Indonesia.

\section{RESULT AND DISCUSSION}

The analyses of the eight journals that have been mentioned above are broken down into two topics, which are

\subsection{Early Childhood in the Context of Disaster}

Children are categorized as vulnerable population (Back et al., 2009; Bruskas \& Care, 2008; Proulx \& Aboud, 2019). Children are categorized so due to the assumption that children are dependent to adults in the aspects of their own safety and their own needs. According to data, the highest rate of disaster victims falls into the category of children and women (Gokhale, 2008; Kousky, 2016). In Indonesia, the data shows that $60 \%$ up to $70 \%$.

Kousky (2016) discussed the damages that could be received by children affected by disasters, which includes the children's physical health, the children's mental health, and interference in the fulfillment of the children's rights in family and education. Children, as the vulnerable population that live in a natural condition with great disaster potentials such as Indonesia, should be dealth with great focus by all parties involved. 
The perspective that children are still at a certain cognitive stage causes children are not involved actively in disaster mitigation. Piaget claims that early childhoods are still in the sensory-motor until preoperational stages (Wood, 2001). In the two stages, children are still considered as egocentric (Lefa, 2014) with the ability of only constructing concrete concepts (Bowman, Donovan, \& Burns, 2000). With this perspective, the involvement of children in disaster mitigation are still questioned, because children are considered not able to understand abstract and complex ideas, such as natural disasters.

However, Burman (2008) deconstructs children development in his book and claims that children have same capability as adult. Children are able to construct abstract ideas. In the discourse of disaster, the claim is supported by Hyogo Framework Action, which states that children have the right to receive knowledge and be involved in disaster risk reduction efforts (UNISDR, 2005). In addition, Izadkhah \& Gibbs (2015)'s research result has also proved the claim by observing children perception regarding earthquakes in their drawing activities. After the children received intervention regarding disaster mitigations, they poured their perception using drawings, and they showed that they could grasp natural disaster concepts and how to face them.

In other words, even though children are included in the vulnerable population, children are not always passive victims (Pfefferbaum et al., 2018). Tatebe \& Mutch (2015) state that even though they have special needs, vulnerable population still deserve the right to have a disaster preparedness education. This can be done by reviewing and adjusting how they can receive the information.

Early childhoods can be invited to work together and become effective communicators of the dangers of disaster (Mitchell, Haynes, Hall, Choong, \& Oven, 2008; Pfefferbaum et al., 2018), thus making the children active agents to increase disaster preparedness and resiliency for both themselves and their community. Prepared behavior in children could be instilled when it is explicitly implemented in their education (Adiyoso \& Kanegae, 2012), including the education in school and in family. Ronan (2008) also states that the earlier a child is invited to contribute in a mitigation program, the impact would be better and greater.

To sum up, children as the member of vulnerable population should be used as a reference to continue improving the ability of children to face disasters. With the potential of children as active agents in disaster mitigation, the children's environment would also indirectly become more alerted to disasters. Thus, the community's resiliency could also be increased.

\subsection{Disaster Mitigation in Early Childhood Education}

The efforts in disaster risk reduction has been implemented wholly (Proulx \& Aboud, 2019), with the publication of Safe School Guidance (Pedoman Sekolah Aman) regulated by Indonesian National Board for Disaster Management (Badan Nasional Penanggulangan Bencana) (BNPB, 2012). The guidance is published for schools and madrasah, where specifically it is still not practical to be used as a guide for implementing disaster mitigation in early childhood education.

The challenges that are faced in implementing the Safe School Guidance in Indonesia are not only each region in Indonesia has different geographical characteristics and different disaster potentials, it also has diverse sociocultural daily lives and education systems. Various adjustments are needed in implementing disaster mitigation in early childhood education in Indonesia.

However, Proulx \& Aboud (2019), during their research, has implemented a disaster risk reduction program in preschools in Sumba. Their research resulted in children showing positive signs in understanding their environment. Even though it cannot be generalized, their research shows that it is possible to implement disaster risk management in early childhood education.

Adiyoso \& Kanegae (2012) state that school has an important role in community in disaster risk reduction efforts. In this case, early childhood education is the closest level of education with the community. Besides the parents' full contribution in the education system, the implementation of early childhood education in Indonesia is still largely community-based (Nunu, 2017), such as Other Similar Early Childhood Education Institution (Satuan PAUD Sejenis) or POSPAUD.

Both the methods or the learning medium that are used in early childhood education institutions are always prepared concretely. Therefore, disaster mitigation in early childhood education could be implemented in a solid and concrete learning situation. The findings from Adiyoso \& Kanegae (2012)'s research shows that by doing disaster simulations or visiting disaster museums, it can increase the children's disaster awareness and preparedness.

Methods of assessing children's understandings of disasters could also be done in an appropriate manner, such as what Izadkhah \& Gibbs (2015) have done by using drawings as interactive medium for kids to deliver their perspective. Drawings are considered as an effective medium to assess children's understanding, because children would give their own interpretation for their own works (Kusumawardhani, 2019).

In Early Childhood Education, Indonesian Ministry of Education and Culture have published the Children Development Level Standard (Standar Tingkat Pencapaian Perkembangan Anak, STPPA) for children 
aged 0-6 years old, where there would be six development level indicators that children should achieve in each stage of age. In STPPA, children's achievement in understanding disaster-related issues should be linked with other indicators. In other words, there are no specific assessment for children achievement in understanding natural disasters and their environment yet.

Early childhood education is not limited to institutions related to early childhood, but also in family environment. Disaster mitigation in early childhood education can be implemented by teachers in early childhood institutions and also by parents in their own home environment. The more that children are placed in situations and environment that are more aware to disasters, the more resilient that children will become to disasters (Elangovan \& Kasi, 2014).

Parents and teachers could access information regarding disasters from several sources. Tatebe \& Mutch (2015) have analyzed in their research some of the NGOs participations in disaster mitigations. Thus, it can support the school, parents, and community to implement disaster mitigation in early childhood education.

\section{CONCLUSION}

Early childhood is one of the vulnerable populations in disasters. However, in the perspective of postdevelopmentalism, early childhoods have the potential to participate and understand crucial issues happened in their own environment. Thus, early childhood education institutions, teachers, and parents should invite and involve children in disaster mitigation programs as early as possible.

Due to the fact that disasters may happen any time, whether the children are at school or at home, children should understand the characteristics of their own environment and how to act when disaster happens. This effort is implemented to reduce disaster risks in children. Besides the need of guidance and regulation that could help both parents and teachers to implement disaster mitigations in children, initiative in reaching more sources to information regarding disaster mitigation and deliver it to children would also be highly suggested as another effort to reduce disaster risks.

\section{ACKNOWLEDGMENT}

This paper is supported by Indonesian Ministry of Education and Culture, in International Conference on Early Childhood Education and Parenting, 2019.

\section{REFERENCES}

Adiyoso, W., \& Kanegae, H. (2012). The effect of different disaster education programs on tsunami preparedness among schoolchildren in Aceh, Indonesia. Disaster Mitigation of Cultural Heritage and Historic Cities, 6(6), 165-172.

Amri, A., Bird, D. K., Ronan, K., Haynes, K., \& Towers, B. (2017). Disaster risk reduction education in Indonesia: challenges and recommendations for scaling up. Natural Hazards and Earth System Sciences, 17(4), 595-612. https://doi.org/10.5194/nhess-17-595-2017

Back, E., Cameron, C., \& Tanner, T. (2009). Children and disaster risk reduction: Taking stock and moving forward. Children in a Changing Climate Research, UNICEF. Brighton: IDS.

Belter, R. W., \& Shannon, M. P. (1993). Impact of natural disasters on children and families. In C. F. Saylor (Ed.), Children and Disasters (pp. 85-103). New York: Plenum Press.

doi:https://doi.org/10.1007/978-1-4757-4766-9_6

Badan Nasional Penanggulangan Bencana (BNBP). (2012). Peraturan Kepala BNPB No. 04 Tahun 2012 tentang Pedoman Penerapan Sekolah/Madrasah Aman dari Bencana. Jakarta: Badan Nasional Penanggulangan Bencana (BNBP)

Bowman, B. T., Donovan, M. S., \& Burns, M. S. (2000). Eager to learn: Educating our preschoolers. Eager to Learn. Washington: National Academy Press. doi:https://doi.org/10.17226/9745

Bruskas, D., \& Care, F. (2008). Children in foster care: a vulnerable population at risk, 21(2), 70-77.

Burman, E. (2008). Deconstructing developmental psychology (second). Sussex: Routledge.

Desfandi, M. (2014). Urgensi Kurikulum Pendidikan Kebencanaan Berbasis Kearifan Lokal Di Indonesia. SOSIO DIDAKTIKA: Social Science Education Journal, 1(2). doi:https://doi.org/10.15408/sd.v1i2.1261

Djalante, R., Garschagen, M., Thomalla, F., \& Shaw, R. (2017). Introduction: Disaster risk reduction in Indonesia: Progress, challenges, and issues. Springer International Publishing. doi:https://doi.org/10.1007/978-3-319-54466-3_1

Elangovan, A. R., \& Kasi, S. (2014). Psychosocial disaster preparedness for school children by teachers. 
International Journal of Disaster Risk Reduction, 12, 119-124. doi:https://doi.org/10.1016/j.ijdrr.2014.12.007

Freeman, C., Nairn, K., \& Gollop, M. (2015). Disaster impact and recovery: What children and young people can tell us. Kotuitui, 10(2), 103-115.

doi:https://doi.org/10.1080/1177083X.2015.1066400

Gokhale, V. (2008). Role of women in disaster management: An analytical study with reference to Indian society. In The 14th World Conference on Earthquake Engineering October (pp. 12-17). Beijing.

Guo, K., \& Kilderry, A. (2018). Teacher accounts of parent involvement in children's education in China. Teaching and Teacher Education, 69, 95-103. doi:https://doi.org/10.1016/j.tate.2017.09.018

Honesti, L., \& Djali, N. (2012). Pendidikan kebencanaan di sekolah - sekolah di Indonesia berdasarkan beberapa sudut pandang disiplin ilmu pengetahuan. Februari Jurnal Momentum, 12(1). Retrieved from http://download.portalgaruda.org/article.php?article $=11$ 8793\&val=5448\&title=Pendidikan Kebencanaan Di Sekolah â“ Sekolah Di Indonesia Berdasarkan Beberapa Sudut Pandang Disiplin Ilmu Pengetahuan

Inter-Agency Standing Committee (IASC). (2013). Mental Health and Psychosocial Support in Emergency Settings. Retrieved from https://mhpss.net/?get=78/1361820836IASCMHPSSforCCCM2013.pdf

Izadkhah, Y. O., \& Gibbs, L. (2015). A study of preschoolers' perceptions of earthquakes through drawing. International Journal of Disaster Risk Reduction, 14, 132-139.

doi:https://doi.org/10.1016/j.ijdrr.2015.06.002

James, E. (2008). Getting ahead of the next disaster: Recent preparedness efforts in Indonesia. Development in Practice, 18(3), 424-429. doi:https://doi.org/10.1080/09614520802030607

Kemendikbud. (2014). Peraturan Menteri Pendidikan dan Kebudayaan Republik Indonesi No 137 Tahun 2014 tentang Standar Nasional Pendidikan Anak Usia Dini. Indonesia.

Kousky, C. (2016). Impacts of natural disasters on children. Future of Children, 26(1), 73-92. doi:https://doi.org/10.1353/foc.2016.0004

Kusumawardhani, D. (2019). The influence of background factors on children's level of learning about disaster: the case of Bandung metropolitan area. Technische Universitat Darmstadt.

Lefa, B. (2014). The Piaget theory of cognitive development: An educational implications. Educational Psychology, 1(9), 1-9. Retrieved from https://www.researchgate.net/publication/252532772_C onstructing_a_theory_of_learner_autonomy_Some_step s_along_the_way

Mitchell, T., Haynes, K., Hall, N., Choong, W., \& Oven, K. (2008). The roles of children and youth in communicating disaster risk. Children, 18(1), 254-279. Retrieved from

http://www.colorado.edu/journals/cye.\%0AAbstract

Mutasa, S., \& Munsaka, E. (2019). Botswana and international policies on the inclusion of disaster risk reduction in the school curriculum: Exploring the missing link. International Journal of Disaster Risk Reduction, 40(April), 101271.

doi:https://doi.org/10.1016/j.ijdrr.2019.101271

Nunu, S. (2017). Implementasi Kebijakan Program Pendidikan Anak Usia Dini (Paud) Pada Dinas Pendidikan Dan Kebudayaan Daerah Provinsi Sulawesi Tengah. Katalogis, 5(2), 146-158.

Pemerintah Republik Indonesia. (2008). Peraturan Pemerintah Republik Indonesia Nomor 21 Tahun 2008 tentang Penyelenggaraan Penanggulangan Bencana. Indonesia.

Pfefferbaum, B., Pfefferbaum, R. L., \& Van Horn, R. L. (2018). Involving children in disaster risk reduction: the importance of participation. European Journal of Psychotraumatology, 9, 1-6. doi:https://doi.org/10.1080/20008198.2018.1425577

Proulx, K., \& Aboud, F. (2019). Disaster risk reduction in early childhood education: Effects on preschool quality and child outcomes. International Journal of Educational Development, 66(January), 1-7. doi:https://doi.org/10.1016/j.ijedudev.2019.01.007

Ronan, K. R., Johnston, D. M., Paton, D., \& Becker, J. (2008). Promoting Child and Family Resilience to Disasters: Effects, Interventions, and Prevention Effectiveness. Children, Youth and Environments, 18(1), 332-353.

doi:https://doi.org/10.7721/chilyoutenvi.18.1.0332

Ronan, K. R., Haynes, K., Towers, B., Alisic, E., Ireland, N., Amri, A., ... \& Petal, M. (2016). Childcentred disaster risk reduction: Can disaster resilience programs reduce risk and increase the resilience of 
children and households?. Australian Journal of Emergency Management, The, 31(3), 49.

Sair, A. (2019). Bencana Dan "Proyek” Kurikulum Kebencanaan Di Sekolah. Journal of Urban Sociology, 1(1), 4. doi:https://doi.org/10.30742/jus.v1i1.560

Septiadi, A. (2012). Perbedaan Sistem Dan Pengetahuan Tanggap Darurat Bencana Kebakaran Sebelum Dan Sesudah Pemberian Pelatihan Pada Gedung Sekolah Dasar Sang Timur Semarang. Jurnal Kesehatan Masyarakat Universitas Diponegoro, 1(2).

Shadbegian, R., Guignet, D., Klemick, H., \& Bui, L. (2019). Early childhood lead exposure and the persistence of educational consequences into adolescence. Environmental Research, 178(April), 108643.

doi:https://doi.org/10.1016/j.envres.2019.108643

Siagian, T. H., Purhadi, P., Suhartono, S., \& Ritonga, H. (2014). Social vulnerability to natural hazards in Indonesia: Driving factors and policy implications. Natural Hazards, 70(2), 1603-1617. doi:https://doi.org/10.1007/s11069-013-0888-3

Stough, L. M., Kang, D., \& Lee, S. (2018). Seven school-related disasters: Lessons for policymakers and school personnel. Education Policy Analysis Archives, 26(August). doi:https://doi.org/10.14507/epaa.26.3698

Subagia, I. W. (2017). Pelatihan Mitigasi Bencana Alam Gempa Bumi Pada Siswa Sekolah Dasar Negeri 1 Pengastulan Kecamatan Seririt Kabupaten Buleleng Bali. JPI (Jurnal Pendidikan Indonesia), 4(1), 585-598. doi:https://doi.org/10.23887/jpi-undiksha.v4i1.4916

Suryani, A. S. (2017). Pemenuhan Kebutuhan Dasar Bidang Kesehatan Lingkungan Bagi Penyintas Bencana Studi di Peovinsi Riau dan Jawa Tengah. Pusat Penelitian Badan Keahlian DPR RI, 8(1), 43-63.

Tatebe, J., \& Mutch, C. (2015). Perspectives on education, children and young people in disaster risk reduction. International Journal of Disaster Risk Reduction, 14, 108-114. doi:https://doi.org/10.1016/j.ijdrr.2015.06.011

Tuswadi, \& Hayashi, T. (2014). Disaster Prevention Education in Merapi Volcano Area Primary Schools: Focusing on Students' Perception and Teachers' Performance. Procedia Environmental Sciences, 20, 668-677.

doi:https://doi.org/10.1016/j.proenv.2014.03.080
UNISDR. (2005). Hyogo framework for action 2005 2015: Building the resilience of nations and communities disasters. Japan.

UNISDR. (2009). Terminologi pengurangan risiko bencana. Bangkok: Asian Disaster Reduction and Response Network. doi:https://doi.org/10.1080/15475440701360168

Wood, K. C., Smith, H., Grossniklaus, D. (2001). Piaget's stages of cognitive development. In M. Orey (Ed.). Emerging perspectives on learning, teaching, and technology. Retrieved from http://projects.coe.uga.edu/epltt/

World Health Organization. (2012). Environmental health emerencies. Retrieved from https://www.who.int/environmental_health_emergencie s/vulnerable_groups/en/ 